\title{
FUNDAMENTALS OF COAST EROSION AND DEFENCE
}

\author{
R. Ro Minikin \\ Maritime Engineering Consultant. \\ Bath, Bngland
}

\begin{abstract}
"Every ultimate fact is but the first of a new series and every general law only a particular fact of some more general law presently to disclose itself". Ralph Waldo Bmerson was not a scientist but he wrote many wise things about human ways and notions. The words of this quotation condense with brevity the whole history of the studies relative to that branch of oceanography devoted to sea behaviour about our shores. Within the last half century there has been a great deal of research on the subject although with different ends in view: some were concerned with marine life and fisheries, some with variation of gravity, others with hydrography and others with the movement of the mobile material on the sea bed, currents and tides. Another type of research of no less importance was the delving into relevant historical records of centuries past of Dutch, French and Italian sea-going map makers. In this connection it was a well known Italian engineer who brought to light the works of a great Finglish chart maker of the Mediterranean, Admiral Henry Smyth (1810) who for twenty years sailed that sea. It is only within recent years that there has been a dissemination of the data collated by these specialist compartmental researches through such Associations as this and it is all to the good of man.
\end{abstract}

The difficulties of hydrodynamic studies are too well-known to require emphasis here excepting to underline the fact that most of the popular quantitative formulae are of a semi-empirical nature. It is therefore easy to appreciate the divergences of opinions of what is essential to a clear understanding and evaluation of the factors that must weigh in the diagnosis of beach behaviour subjected to the complex sea action.

It is the purpose of this paper to examine briefly those things recorded from authoritative observations of the phenomena and the reasons and the remedies more usually proposed, or executed, for the given conditions in various countries. The author has already suggested elsewhere that the personal approach to these problems should be definitely linked to a sea-sense, in other words a keen interest in and contact with the sea in all its moods.

I therefore propose to give brief outlines of several of the more important, and perhaps instructive, examples of coastal problems from European countries, and the remedies aplied. In so doing I have tried to relieve myself of any preconceived bias and have approached the matters as a student seeking optimum solutions to tantalising problems. 


\section{EIVILAND}

CHESII BANK.

On the south const of England, the exquisite Iyme Bay of crescentic form has at the north east quarter from Bridport to Portland a unique and remarkable shingle beach. Beginning at Bridport as a narrow ribbon of small shingle it extends for 16 miles south eastward to end in a massive embankment of larger shingle against the rocky prominence of Portland Isle. At Bridport it rises to a height of about 18 feet above mean water level increasing to a height of 23 feet at Abbotsbury where it leaves the mainland and in the form of an embankment, or spit, continues to Portland where it reaches a height of 45 feet and effects the closure of a narrow stretch of water called the Fleet. For centuries this accumulation of shingle has maintained its natural equilibrium subjected at times to seasonal changes on the seaward face but recovery is made within short periods afterwards.

Although in the distant past this structure may have began as a spit its growth subsequently could not have been achieved by the same natural mechanism. Its aligmment is directly normal to frontal attacks from the prevalent winds and storms from the south west and it is fully exposed to the Atlantic gales sweeping up the English Channel. That its main constructive mechanism was, and is, due to wave action seems certain, but as many learned men and societies have failed to find any comprehensive explanation of its being from superficial observation it is probable that the secret is hidden under water.

The undeniable fact is that there is some combination of forces which has been able to maintain stability against all assaults of the sea and weather over the centuries.

\section{SELSEY BIII.}

A few miles to the east of Portsmouth lies Selsey Bill which protrudes like a nose into the English Chamel. It is low lying land of sedimentary material which over some decades has suffered erosion at the rate of 20 feet annually despite protection efforts and much damage has been done to property of the coast villages. The stretch of coast most severely affected is about 1 mile long and is a zero point of littoral drift which divides into two strearos one travelling westwards and the other eastwards. The tidal current is particularly severe approaching about 4 knots on the flood close inshore. The mean tidal range is about 12 feet. A point of note is that in the year 1920 a substantial lifeboat house and alipway was constructed on the beach where the more serious erosion has taken place. The boat house was 60 feet landward of the H. T. O.S.T. line 
and the slipwry ran seaward for 250 feet ending just below low water line. The whole construction was supported on piles driven into the hard stratum underlying the beach. The lifeboat house which is connected to the shore by a gangway has thus progressively been situated further and further out to sea. The particular point to note about this erosion is that it extended in depth to the hard strata (Iower Greensand) only, about 9 feet below low water, and after demolishing the original land of low resistance and the beach covering it for over 600 feet, the new seabed is at no greater depth than the old in front of the slipway. The question then arises if longitudinal works had been carried out about the slipway when erected would the land and property have been saved.

\section{SEORLFA}

Another example worthy of study is to be found at Shoreham which Iles almost central in the flat crescentic bay which lies between Selsey Bill and Beachy Head. For several hundred years shingle has accumulated in quantity along the foreshore despite all the efforts of $\operatorname{man}$ to by-pass it beyond, even to the present day. Shoreham is the largest of the small sea ports between Dover and Southampton and the harbour entrance is situated about the centre of what was originally a shingle spit which grow out from Lanoing towards the east across the mouth of the small river Adur until it: reached the mainland again at Aldrington. The movements and the fluctuations of growth and breaches have been carefully recorded from 1580 A.D. whilst ocourional mantion has beon made of it in historioal documents from 1086 A. D Thas there exists a fairly comprehonsive record of the forouhore oharacteristics and behaviour for, at least, 400 years. The littoral drift is from wost to east.

Lbout the year 1840 the West entrance pier to the harbour which was of openwork timber construation had to be planked up to prevent the spili of ahingle into the harbour. This still did not prove auficient for the purpose. A large groyne was therefore erected to the west of the pier with extension of 260 feet further into the Channol. This also was ineffective for in 1872 a large bank of ahingle was thrown across the harbour entrance completely blocking it. The west pier was leagthened for a third time by 200 feet but as before it was useless in spite of the fact that during the accumilation a large amount of shingle was dredged and transported elsewhere.

On one cosasion no less than 25,000 tons were dredged, transported, end dumped about 200 feet samand of the dopleted Brighton beaches in a bank bolow low water. A lierge quantity of this was mashed up to form a boach 8 foet higher at the promenade wail.

Recontly in 1943 a shingle bar grew again alcmost completely ecross the entrance. Is a remedy in 1944, dospite the old history of 
the port a massive conorete groyne was built to the wost of the fiest pier extending 100 feet beyond the pierhead. As mould be expected the same trouble has again arisen desplte the removal of large mounts of shingle. It should be noted that the beaches to the wert of Shoraham are well furnished with groynes as is the Shorehan beach to the east.

Despite all this evidence of failure to achieve the deaired aim a new project shows the recently constructed Hamblin groyne is to be further extended out to sea for 500 foet, in other words, a ropetition of the unsuccessful methods of the past on a more drastic scale.

\section{HASTINGS TO FOLKESTONE.}

Between Hastings and Folbestone there is a stretch of const which well repays a close study. Hastings is foirly woll supplied with shingle by the littoral drift whiah is west to east along this coast and the beaches fronting this rejort are satisfactorily beld by the narrow concrete parallel slded grojmes rooted in the vortical promenade wall and sloping semard at about 1 in 10. The crome are rounded. Along the coast for a few miles, from Fairlight Cliffs to the small river Rother, debouohing into Riro Bey, a long combankment protects the land about Winoholsea. This embaniment. comprises two parallel rows of boarded timber, crossbraced, and strengthened vertically with timber piles driven into the beach. The spece between the rows is backfillod with shingle from the beach, and the

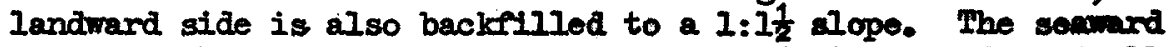
front of this wall is vertical and fifty feet searard a parallel and contimous ron of $9^{n} \times 9^{\prime \prime}$ piles spaced at $18^{\prime \prime}$ centres are drivon into the beach to act as wave breabers. The area of the beach between the wall and the line of wavebreakers is divided, by timber planking, into compartments about 150 - 200 feet long. Some of these partitions extend as stub groynes about 30 feet to the soawnd sido. of the wave breakers and same, at every fourth partition,are extended into low timber groynes ruming down to the low water line over the flat sandy beach.

In the compartments at the wall the normal condition is a moderate accretion of shingle up to a height of 5 - 6 foot against the wall and partitions and thinning out to little above sand lovel at the midale. About the short groynes there is usually a triangular heap of shingle. Just about the sea and of these stub groynes thore is a defint te line of demaroation between shingle and sand rumaing almost parallel to line of wave breabers. The sand besch to low water is very flat and here and there on its surface, when dxy, can be seen thin groups of shingle scattered about showing track of travel towards the high water Iine. Before the erection of this defence the original embankmont was frequently bresobod and busardod the safety of the low lying land around Tinoheleen and Boe. It will 
be gathered that after the completion of these works the accretion of shingle as an auxiliary defence was still not sufficient to relieve anxiety. Another factor of disadvantageous character is the low height of the embankment crown above high water ( 7 feet) so that too great dependence is placed upon the effectiveness of the wave breaker palisade. However it has given great satisfaction over many years, and hazards to the understanding professional mind. are not always appreciated by administrative authorities until serious mishaps occur.

The terminal groyne of this system at the mouth of the River Rother has been lengthened considerably to prevent the shingle entering the harbour channel, but as in the case of Shoreham the trouble still recurs.

Just beyond the east pier of the river Rother the coast line becomes the root of an ancient and enormous accumulation of sea driven shingle extending into the well known cuspate foreland of Dungeness which has grown out to sea for about 10 miles and covers about 25 square miles of what was once sea-bed. This headland grows in size about 6 - 7 feet anmually pushing out over a muddy sea-bed in 10 fathoms of water with a steep seaward slope. As the littoral drift is west to east all this increase of shingle build up must have traversed the sea-bed or beaches fronting the above mentioned timber wall, groynes and wave breakers. It would therefore appear that as these beaches have only meagre supplies above L.W. a large quantity of mobile material must travel underwater.

\section{TENTRK}

It would seem that no great concern was felt about coast erosion in Denmark until about the beginning of this century when protection moasures were more seriously undertaken to defend the barriers, or natural sandspits, enclosing the lagoons, on the North sea coast line. Most of the westerm coastal land of Denmark is of sedimentary material, sand and glacial drift, generally 15 to 20 feet high above sea level. There are a few headlands about 100 to 200 feet high said to owe their origin to glaciers. The tidal range on the most difficult erosive stretch is one foot at Bulbjaerg to the north and two feet at Ringkoben Inlet to the south, in a distance of about 100 miles. Off shore the sea is shallow and covered with series of sand banks migrating northwards. The immediate foreshores have a slope of 1:50 to 1:75; the 5 fathom depth lying about half a mile from the beach. The predominant winds are westerly and from the direction of the greatest fetch, approximately 360 miles.

Ther is little doubt that this stretch of coast in time past, and not so long ago, has been favoured with ample supplies of sand which were userully deposited along the beaches and formed spits across the mouths of coast indentations. Three of these spits, 
Iime, Nissum, and Ringkoben represent no less than 30 per cent of the length of the coastal stretch considered. The first named commenced at Borbjaerg and stretched northwards to Agger, a distance of 11 miles, where same 80 years ago there was only a narrow navigable channel separating the head of the spit from the mainland.

About that time a westerly gale closed up this chamel and breached the spit about midway in its length. There was a vast area of water surface contained by this barrier, or spit, but the rise and fall of the tide about the point of the breach was only 16 inches, so no great inconvenience developed from that source. Nevertheless there was now a freer access and expansion of the heaped up storm waters which sometimes caused 5 feet difference of hydraulic head between the sea and the inlet levels setting up a 6 knots current of sand laden water. As could be expected tongues of sand radiated eventually from this new entrance to the lagoon. The spit heads were thus turned into the quieter water. At that time it would appear that the littoral drift along this portion of the coast was south to north but nowadays it is reversed.

At Iodbjaerg, about 8 miles further north the littoral drift bifurcates: the stronger supply proceeding northwards to the Skaw and the weaker supply turming south towards Horns Reef, in which place there is a considerable and continuous accretion.

The appearance of erosion about the seaward flanks of the north and south arms of the spit and fears of further breaches forced the Govermment to erect protection works in the form of sand barriers, or dykes, and tipped rubble groynes. The early groynes were not successful. neither functionally nor structurally. The loose rubble was dispersed and slumped into the sandy bed. The coast line continued receding about 10 feet annually reaching a maximum at the tips of both arms of the barrier. Careful observation of the sed variations showed there was for some miles along the south arm an apparent reversal of the littoral drift, so that in effect there was at the entrance to the inlet a meeting of the littoral drifts from the north and from the south.

Within recent years the technique of construction of the groynes was changed. They are now built up with a central core of pre-cast concrete blocks $4-6$ tons weight coursed in tiers horizontally out to sea for at least 400 feet with the orom 4 feet above mean water level. The crown is about 12 feet wide and the base 15 feet wide. On both flanks pre-cast 4 tons concrete blocks are tipped to a $1: 2$ slope to meet the crom level. These groynes are about 400 feet shorter than the original. Since their use on the Lime barrier the recession of the coast line has been slowed down 75 per cent. At the entrance channel the groyne at the northern head is rm out to sea as a breakwater for about 900 jards whilst that on the southern head is about 
'300 yards. It is bighly probable that the disposition of these terminal groynes at the inlet entrance and the super-elevation of high water during westerly gales has caused this apparent local reversal of littoral drift. The unfortunate result of this phenomenon is that the soa-mard flenks of the barriers are robbed annually of the one million cubic yards of sand deposited in the lagoon.

Fron Iine Inlet to Horns Reef a distance of 80 miles is sparsely protected except at Bovbjacrg where aimilar groynes to those of the above ystem are built. The reduction of the erosion achieved is also about 75 per cent, however the completion of these groynes initiated to the lee of the Borbjaerg system a severe and serious erosion of the valuable agricultural mainland immodiately beyond the last groyne, land which had hitherto been free from erosion. These 40 - 50 feet high cliffs have suffered erosion at the rate of 25 feet annually for a number of years.

For 30 miles further south there is erosion of the coast line of varying amount up to 6 foet annually at Nissum Inlet barriers; then for the remaining 40 miles to Horns Reef there is progressive accretion rowching its pook at the latter point to no less than 40 feet annually.

\section{HOIT NND}

In the early days of February 1953 the terrific storm and sea surge whioh assailed the Notherlands and inundated a large part of the . country aroused the sympathies and admiration of the world towards those courageous people who gained their Ilvelihood virtually below sea level. No loss couragoous was the stalwart Dr. Van Veen, the engineer in chief, who lod and orgenised the reconquest of the submerged lands. When arrare of the mogitude of the disaster his remark was "I knew it could heppen but we Dutchmen never give up. Every 500 years a great deluge has orerwhelmed us but I am neither shaken nor discouraged. We must, indeed we will with God's help, take back all the sea has claimed".

I am glad to say within 12 months of those bold words the last olowure of the ronewed defonces was completed and strengthened. A gigantic task well and truly performed.

The Dutch problem is unique and is peculiar to Holland, geagraphically, bathomotrically and morphologically. The North sea is ahellew and is replete with an enormous and mobile series of sea-bed sand benks traveling northwards, a few milos from the Dutch coast and Jet providing a mongre and insufficient supply of replentishment for the beaches. It is common knowledge that the man-made dykes beep the seamater out, but not so well appreciated that the vanguard of the defence against erosion takes the form of systems of groynes. Two or three yoars ago I expressed, in a paper, astonishment at what I thought to bo an extravagant une of this manner of defence, labouring 
under the notion that they were erected, as in general use, to trap material of the littoral drift.

I was corrected in this assumption.

Dr. Van Veen explained. The Dutch want artificial capes. Since Holland has no cliffs it has very little littoral drift and what there is, is unreliable and halting. The whole coast has a tendency to recede slowly. "We could not afford to lose ground in places of recession and therefore defended those places, of course diminishing the available littoral drift by doing so. We have learned to look under water. The tidal currents had to be kept off, well away from the shore. The cape-like expensive groynes have kept the depth-line of 7 metres well out of the shore and kept the whole low country behind it safe. Of one thing we are sure: there is no other why to stop erosion than by making or keeping strong capes".

From an authority of Dr. Van Veen's experience and sagacity such arguments are unassailable. In this comection I should like to make it clear that the matter discussed referred to Scheveningen on the actual North sea coast line and not within the shelter of the several rivers' estuaries, where almost all of the scores of breaches occurred. As a matter of fact only one occurred at Scheveningen, and only three on the North Sea exposed coast which fronted the direction of the storm.

It will be gathered from the above that the Dutch practice is concentrated on the preservation of the beach profile and not designed to encourage beach accretion. The particular range of groynes mentioned above are massive structures with a section base width of 80 feet and 12 feet high from the base to the crom which is 30 feet wide. The core is of layers of stone filled fascine mattresses; the top layer is blanketed with stran mattresses which are then staked and covered to a hump form with rubble. Over this for a central width of 20 feet large basalt blocks are laid and confined at tho outer edges with timber stakes of stout scantling. Then on both Planks heavy rubble is tipped to completely cover the whole, outside of the crom: this is then grouted with bitumen mastic. Groynes built in this manner remain in good condition for about six years, others: not treated with bitumen require mach maintenance.

The crowns of the groynes are almost parallel to the beach profiles, and run out to sea for about 350 feet bejond the low water line; the extremities are fanned out to prevent scour. The root of the groyme in the langitudinal dyke is always strangthened.

High groynes however are not favoured in those places where accretion is possible and in the event of a depletion of mobile material already gained the groynes are lowerod to reduce turbulence about them. The reduction of height is not haphazard but is computod in relation to the known characteristics of the particular besch 
behaviour.

A notable feature of the Dutch sea defence practice is that during. the sumer months a thorough research is carried out to investigate the natural phonomima governing the mechanics of marine behaviour: a practice worthy of emulation even in countries less afflicted by the ravages of the sea.

The Dutch systems of longitudinal dykes have always impressed me as permanent artificial beaches which are skillfully adapted not only to the sea conditions but to the necessities of the land behind. Furthermore they crystallize into practice with elegant simplicity the stern lessons they have leamed from Nature. On low lying ground at mean water level the base of the dyke may be 400 feet wide with the crom berm 25 leet above mean water level. From the berm to the toe the distance may be about 250 feet. The toe is usually at about low water level. A point to note about the toe profile up to about 12 feet above high water level is that it is usually convex, a close relationship to the natural form of accretion of mobile material and suitably adapted to take the wave break. It will be appreciated that the flat seawrard slope is akin to natural beaches and, though not pervious like the latter, are equally suitable to easily absorb the send of the beach breaker.

As the height of the ground behind the dyke increases the base width of the dyke is decreased and the forward slope shortened and strengthened, but seldom exceeding 1:5 up to 12 feet above high water. The crom in most cases is carried abote dry ground level, particularly. in exposed situations facing deep water, and the upper forward slopes to the crom berm are then provided vith concrete slabbing with projecting concrete chequer tongues to break up gale wave send and backmash.

\section{BEHGIUT}

The forty miles of the Belgian coast from La Panne to Le Zoute is one vast sandy beach exploited almost entirely by the holiday seaside resorts. The delightful sand playgrounds and good bathing has for many years been a magnetic attraction for Buropeans. Not so long ago this oxtensive strand was backed almost for the ontire length with sand dunes, but with its increasing popularity as a tourist centre long stretches of the dunes have been levelled and promenade sea walls (digues) have taken their place. Besides providing amenities these walls formed the longitudinal defence works to valuable property of the resorts: the most valuable property being frequently constructed in the most vulnorable but pleasant positions, in other words on the sea front and rathor close to high water line.

Aberat the beginning of this century the harbour wall at Zeebruge was constructed curving out to sea in a wide arc and cutting trans- 
versely across the tidal stream for about 2,000 yards from the shore. From about the point where the low water line intersected with the line of the mole there began an open viaduct 1,000 feet long linking the main wall to the shore. This opening between sea and harbour was inserted for two reasons. It was foreseen that (a) the strong and steady littoral drift moving northwards would be interfered with considerably if all the tidal stream were obstructed and consequently the resorts and beaches to the north would be robbed of sand replenishment; also (b) the large amount of silt and sand in suspension during bad weather would be deposited around the head of the mole into the harbour if there were no current running through the latter. In spite of this precaution all the se things did happen.

The coast line to the north began to show signs of erosion and the defences had to be strengthened from Zeebruge to Le Zoute. The erosion still continues and it has been proposed to lengthen the groynes for some distance below low water. Not only to the north of Zeebruge has there been unusual depletion but to the south also. Over the several decades that I have observed these shores never have I seen the beaches so thin between Blankenberge and Westende with the exception of about two kilometres of sand beach at Breedene. It is more than probable that the cause lies under water.

The flood stream along the Belgian coast rums strongly close inshore whereas the ebb is weaker and favours charmels further out to sea. The average duration of the rising tide is 5.5 hours and the falling tide 6.43 hours. The peak rise takes place between 3 hours and one hour before high water representing 60 per cent of the total rise whereas the falling tide is more or less uniform.

The Dutch Rijkswaterstaat under the direction of Dr. Van Veen as a result of researches of the sea-bed along this littoral draughted a most instructive chart of the sand banks off this coast. He found that the flood currents carved out charmels urmistakeably directed close inshore and almost parallel with the shore line. Distinct ebb chamels lay about ten miles or so off shore. It is from these sandbanks off shore that the replenishment for the Belgian beaches must come. I feel that I must again quote Dr. Van Veen. We must know the bottom of our waters as if it were the soil of our own garden".

His work was carried out by echo sounders and ingenious especially devised and simple instruments. How much more effective could his investigation have been had television cameras been available?

It will perhaps have been gathered that the Belgian practice on coast defence has been built up on what was a favourable accretive littoral, and the confidence so begotten in a sufficiency of sand supply directed the engineers to the sole aim of preserving the full amenties of their fine beaches. This took the form of dividing up 
the almost temperamental sandy beaches by constructing strong walls, or groynes, normal to the digues to confine the sand in compartments from the low water line. In the construction of the groynes to a humped back cross section the side slopes and sea-end were made gentle with the crown height about $1 \frac{1}{2}$ metres above the beach when constructed. They were rooted in the toe of the longitudinal dykes with transport ramps to the aprons for vehicular traffic. An important feature was that the surface was fair without any sort of obstruction protruding. They were originally about half as wide as the Dutch groynes already described. I think it is indisputable that for decades they gave good service with comparatively slight maintenance although constructed with a sand core covered with staked fascines and in some cases a finish with brick on edge. Nowadays they are faced with coursed rough squared basalt blocks of $\frac{3}{8}$ to $\frac{1}{2}$ ton weight with stakes at the verges and grouted with bitumen.

Within recent years I have noted certain additions to groynes the purpose of which is not clear. At Blankenberge the top rounded surface of a groyne is covered with cast in concrete blocks ( $8^{\prime \prime} \times 40^{\prime \prime}$ in plan) placed apart in a herring bone pattern and projecting about 8" above. At Ostende a new groyne was constructed to the usual Belgian pattern, and on the top surface, rows of stakes in the longitudinal joints of the face blocks supported a $10^{\prime \prime}$ high willow or chestnut closely woven fencing, for the whole length. This type of fencing is admirable as a wind sand trap but for an under water groyne its efficacy is doubtful. However within two seasons it was dispensed with, and the groyne surface was changed to the usual pattern with the additional benefit of bitumen mastic jointing of the blocks.

\section{FRANCE}

I have heard Frenchmen say with some degree of concern that in France there is no system of coast defence - there is only expense. But one must take that with a huge grain of salt, for a tour of the French coasts will show examples of nearly all systems, new and old, that have erer been tried out. They are not always elaborate, or of striking appearance, but the ideas were there despite the lack of funds. What I imagine was the meaning underlying my friends' remarks was that in France there was no definite practice, or duplication, that could be classified as national and successful. The fact of the matter is that France, as ever, expresses localized individuality even in coastal works and, after all, who is to say that one pattern and one pattern only will answer the complexities involved.

The boarded type of timber groyne so common in England is not in favour in France excepting for temporary work, and within recent years several designs of reinforced pre-cast concrete groynes have been tried out particularly in the Calvados. These are comprised of transversal pre-cast concrete frames supported on piles driven into the beach and flanked with steel sheet piling. The $5^{n}$ thick deck of the groyne is 
humped back and is formed by placing large numbers of pre-cast units, like the single steps of a staircase, between the frames, and castingin their extremities with concrete. The groynes are about 36 feet wide, and rise to a height of about 7 feet above the original beach. The other type of similar dimensions overall has a smooth surface with a deck 16" thick and a distorted sine curve hump. A curious point about these groynes is that in cross section they are asymmetrical. These new constructions are so unorthodox that their behaviour and effects should be of great interest.

The coast line of liedoc between Soulac and the Pointe de Grave, fully exposed to the Atlantic, has suffered a great deal from wave action and because of the importance of its preservation to the stability of the navigable entrance chamel of the Gironde estuary the authorities have spared no expense to provide adequate protection. Bold efforts and ingenious devices have been made to keep the sea back; and considering the exposure and difficulties of terrain they have been rewarded, even if not 100 per cent successful. The Arros wave breakers are of a long and short leg zig-zag pattern with the points sea-ward and the short leg oriented normal to the direction of the predominating gales (S.W.) and the long legs parallel. The sea-ward angular points are about 650 feet apart, and about 650 feet from the toe of the dunes, the inmer angle is 300 feet from the dumes. This area of the beach is divided up into 6 compartments in a length of 6,600 feet. The top of the wave breaker is about high water springs, and constructed of concrete blocks dowelled together and protected on the sea side with natural rock ( 3 to 6 tons) at $I$ in $2 \frac{1}{2}$. This zig-zag (or saw-toothed) alignment has given good results but the neighbouring system in the Anse des Huttes has not had the same good fortune, it has been destroyed completely and a new system is being constructed in the rear of the old.

The old wave breaker wall was of novel construction having on the front sea-ward face staggered series of narrow stairs formed by concrete blocks coursed into the main wall of blocks, as though each set of stairs was placed one step backwards in every three sets.

The present new construction of which two compartments, or lagoons, are completed is designed in section very similar to the wall section of Arros but somewhat sturdier, and with the added support of steel sheet piling on both flanks. The aligment is almost straight.

The points of difference of this new construction and that of Arros are worthy of note and are, (a) the sea-ward slope of the rock fill is 1 in 2 as against $I$ in $2 \frac{1}{2}$ to 3 , (b) the fill is comprised of a central core of chalk rock of 2 to 6 tons with face rocks of greiss 4 to 9 tons, (specific gravity 2.85) as against ordinary rock 3 to 6 tons at 40 tons per metre run at Arros.

In 1950 - 51 the well known Neyrpic Laboratories investigated the problem in its entirety and reccmended a natural rock wave breaker 
with a seaward slope of $2: 1$ and back slope of $1: 1$ with a moderate berm. The core to be of limestone, or hard chalk, from 150 - 1000 pounds and the face blocks to be of hard rock 3 to 6 tons weight grouted with bitumen. The élastic and cohesive nature of this type of wall and its ease of construction are too well known to require further description.

\section{SPATN}

The Mediterranean coast of Spain has little tidal range and the littoral is generally of greater steepness than on the coasts of the North Sea and English Channel. One gets the impression that Spain has derived a good deal of its practice on sea defence from Italian influence, and the few points of national particularity appear to be, (a) Transverse and longitudinal defence take the form of rubble mounds, (b) It is taken for granted that off shore banks of sand are available for beach replenishment, (c) that the best method of shore protection is to build rabble breakwaters into the sea to a depth of water about one and a half times the height of storm wave in the locality, (d) that the groyne should be normal to the coast and its crom should be at least half the wave height above mean sea level.

It will be appreciated that such general rules whilst they have the element of simplicity require constructions absorbing large volumes of rock since the plunge line of the breakers is confined within the flanks of the groynes. They are therefore built to substantial

dimensions, a crown width of 20 - 30 feet of $3-4$ tons quarried blocks. They have a central core of quarry run containing a sufficient percentage of small material to render the structure sand-tight. In no case are groynes constructed with submerged crowns at mean sea level, in fact such a condition is considered inefficient. Short groynes are not approved as the whole intention is to form compartments to contain the turbulence and send of the breakers.

Generally on coasts of sedimentary strata the groyne system is linked up with a longitudinal defence wall of tipped rubble in two layers of a normal thickness of 8 to 10 feet at a slope of $1: 1 \frac{1}{2}$ to 1:2. This is formed in two layers, the inner of $2-10$ hundredweight quarry stone and the outer face of $3-4$ tons quarry stone with toe and crown aprons of substantial proportions.

One also notes the precise adherence to mathematical formulae for block weights, slopes and wave heights.

\section{PORTUGAL}

The Portuguese have not developed any particular system of coast erosion defence although so fully exposed to maximum fetch of the wide Atlantic. The main impression is that generally erosion has only become 
a problem with which to wrestle when some small fishing port has passed through the threatening stage and has sustained serious damage. The fact is that little serious attention has been given to the subject. Where defence works have been carried out they have all the appearance of temporary measures and scarcity of funds: that they are works of emergency there is little doubt. The continental platform is very narrow and the huge Atlantic waves can approach to within a few thousand yards of the coast.

The littoral drift mostly of sand is north to south over a long stretch of the northerm provinces but owing to the constant turbulence along the shores there is great difficulty in maintaining the beaches. To provide adequate works for this coast would require the expenditure of large sums to construct and to maintain.

\section{ITALY.}

I feel it would be proper to preface notes about Italian practice to pay tribute to the pioneering works of her sons in scientific research of the littoral since first initiated by the great Leonardo da Vinci. This unique genius, engineer, philocopher and artist excelled in all he undertook and even in his day his fame spread throughout the cultured world. In his studies (1502 A. D. $_{0}$ ) of the Cesenatico coast on the Adriatic Sea north of Rimini he left notes of his observations which might have been written yesterday: about the mechanism of oscillating waves, the movement of detritus over the sea-bed, the breaking wave in shallow water and the land defence against sea erosion.

Fis fame reached France and Francois the First invited him to investigate the constructions necessary to make the then small port of Havre the foremost port of the world. Regarding this it is interesting to recall that the Grand Admiral Bomivet said in reporting the appointment of the construction engineer, one, "Guyon le Roy, horme ardent, avisé, et pas plus mauvais ingenieur que tel Italien qui fut venu de Lombardie".

The substance of some of Ieonardo's comments on the Cesenatico littoral was: that stretches of the beach which are in the process of accretion are usually those which have been thinly favoured with Iittoral drift supply to begin with, or have already been subjected to severe depletion; whereas those beaches suffering erosion are more usually. those with a steep foreshore. Thus it happens on a depleted shore, and given certain morphological conditions, a series of banks of mobile material are formed on the sea-bed off shore. These banks are not stationary but continue to advance underwater. The concave profile is that which everywhere characterises the work of erosion whilst the convex profile indicates the work of accretion. The underwater travelling sand banks are usually humped back and their surface is wrinkled.

Since Ieonardo's time many Italian engineers and oceanographers 
have confirmed his acute observations on sea behaviour about the coasts to which he had given attention.

However, to get to more recent times a well known Italian engineer the late Paolo Cornaglia after much experience and study published (1890) a theory "Flutto di fondo" (bottom wave). Whilst whole heartediy accepted in Italy it was not well received in France, where the criticism, which was possibly due to misconception, oentred around mathematical evaluations and not the argument.

As we are more directly concerned with the latter it would be profitable to give a brief outline of Cornaglia's argument relevant to the littoral.

(a) From the plunge line to the shore. After the break the mechanism of the wave is destroyed and there exists simply the fall of the water jet on the beach in virtue of its own wight. The direction of the retumof this water to the sea does not correspond with the approach direotion unless this itself was directly normal with the beach contours. The approach direction to the shore although influenced by the contours is muoh more affected by the impelling force of the wind, whereas the return flow is constant, that is normal with the contours; the refore from the break to the return the path of a water particle is of a sawtoothed pattern, with a degree of sharpness dependent on the direction of wave approach and the angle it makes with the normal to the contours.

(b) Sea-wards of the plunge line.

The direction of travel of the visible surface wave is on the same line for both the direct and the return phase, and varies according to the direction of the force producing the agitation and the surrounding conditions.

Out at sea, away from the plunge line, if the direction of the waves is not parallel to the run of the contours a particle of sedimentary material will be impelled forwards, with components in the direction of a contour line and normal with it either directly torrards or away from the shore with trajectories of constant direction but in alternate sonses. If the forward pulse is shorewards to the contours and predominates over the return then the tendency is towards the beach, on the other hand if the return pulse predominates the material will move progressively seawards.

If the forward and return impulses are of equal energy and have coincident trajectories the partiole will be tossed up and down and will always retum to its origin.

Cornaglia sums up this argument as follows.

Where a particle is acted on by two forces of equal energy first 
forward and then backward it can then be said to be in a neutral point.

The succession of such points along the littoral is spoken of as the "Neutral line", which is at greater depths as the agitation is greater and the particles smaller and lighter. However in the same point of the sea-bed and for a given wave height, particles of different size, shape and specific gravity have a different neutral line. In sum without the conception of a neutral line it would be impossible to explain how the beaches in certain circumstances are accreted and in others are depleted. If there is not a predominance of the forward wave over the return, the sea-bed material, under the action of the component of its own weight parallel to the latter, shall be constantly everywhere translated always towards the sea and the beach will deplete to the point of disappearance; on the other hand if the direct wave predominates there will be accretion.

I take leave to submit that this is the most simple and comprehensive explanation of beach phenomena.

The first impression of Italian coast defence works in that picturesque land is the sheer ugliness. They seem out of keeping in their sombre colour and mis-shapen craziness, without apparent purpose, to the surrounding landscape. However to the man who put them there they serve, and it appears, successfully the purpose assigned to them. In point of fact they are simply long embankments of dumped quarry rock aligned parallel with, or slightly inclined to, the coast line, and lying out to sea, on the average, 300 feet, although in some cases they are as close as 100 - 150 feet. They vary considerably in length and those which are long are usually provided with gaps sufficiently wide to obtain maximum nourishment from the littoral drift. The cross section is trapezoidal, the top width is recommended to be not less than 16 feet unless it is landward of the plunge line of fair gales. The height of the berm above mean water level varies from 3 to 7 feet. In the more sheltered areas, or shallow foreshore, the sea-ward slope can be 1 in 1.5 to 1 in 2 but for more exposed situations it should never be less than 1 in 3 . In most cases the landward slope is 1 in 1.

Generally the exposed above water surface of the natural rock presents a jagged appearance but of those situated about the Gulf of Naples the surface rocks appear to have been hand placed and bedded. In the same place there are examples of slightly curved aligrments with the convexity to sea-ward. At Chiavari in the Gulf of Genoa the series of lengths, each about 300 feet, are all parallel but inclined slightly across the system alignment. Both ends of each length, excepting the far extremities of the system, overlap just sufficient to prevent frontal waves riding through the gaps which are about 60 feet wide.

It is obvious that the storm wave height and the respective plunge line are the ruling factors in the location of the defence from the 
shore. This must be observed in Nature and not assumed, economy in design is thereby achieved. The site is therefore fixed landwards of the plunge line of the maximum observed storm wave. The reason for this is to avoid the shock on the loose boulders and to capture as much suspended sand as possible from the heavily charged waves, by expansion in the quieter water, after passing through the gaps. Naturally for waves of lesser height there are sure to be those which break on the rock wall, and for those the dimensions of the wall are fixed. Indeed in some places where valuable property near the water line is threatened a single isolated length is constructed in water about 10 feet deep like a thin rectangular island 30 feet wide at the water line and a base width of 80 feet. On initial construction the gaps are scmetimes made purposely wide and narrowed progressively after observation of the amount of replenishment of the beach shows to be necessary. One important practical point is that should some part of the mound above water level be washed away and not repaired a succeeding storm will probably carve out a valley in the beach immediately in the rear of the depression. Groymes are not favoured.

\section{REFLECTIONS.}

\section{IITMTORAL DRIET.}

In the first place I would like to emphasize that we do not seek the causes of erosion. They are visible and happen everywhere and all the time. The phenomenon is immutable and our learmed philosophers and geologists have made the matter so plain that it is now elementary, and in the knowledge of all schoolboys. What we do seek however is the most simple and direct manner in which to protect the vulnerable and generally valuable parts of our coasts against those sea forces which destroy. Any engineer could with confidence guarantee to defend rock cliffs against sea erosion - in fact it is done everyday. That is no problem, and I feel that high cliffs should be allowed to erode for the benefits derived.' We all know that in the process of rock cliff erosion, by weather and sea, large portions collapse in the sea. In their subsequent disintegration they furmish a large amount of loose material which eventually may prove useful to the weaker neighbouring cossts.

The part played by rivers and torrents although considerable will be neglected in our argument.

Erosion of low lying alluvial land or clay cliffs is generally useless as far as we are concerned, indeed it may be harmful as for the most part the eventual product under sea action becomes mud and silt. The detritus from rock destruction however after being pounded to small sizes and rounded shapes is catapulted by wave explosions from the neighbourhood of the rock bed where the turbulence does not allow the particles to rest. It has been said that a large boulder 
can be cracked to pebbles in 10 years. Observation will show that rock surfaces do not favour the repose of loose material or sand particles, even in pot holes. Eventually they find themselves on a flatter sea-bed and more receptive area as some will find their like already there. Now begins a very different excursion, under the oscillating action of the waves and the stronger effect of the tidal currents and the easier travel over a flat surface. They also have the benefit of the urge to travel given by the slight heaving of the bed on the passage of the surface wave.

Shingle does not like the neighbourhood of rock ledges, sand may accumulate near them but not shingle. The result is the meandering over the littoral backwards and forwards, left and right, and progressively aray from the origin. The waves begin to sort out the particles in a sort of selective grading in the position in which they find themselves at any one time. Some may find a depression in the sea-bed sloping steeper sea-wards where the forward pulse of the wave is weaker than the return plus gravity so that the resultant motion of these particles is sea-wards and they join the throng proceeding towards the littoral slope. Others, which have just avoided the change in bed slope, may do a sort of sentry duty first moving one way and then back again, but, in the tide way which may be across the direction of the waves, it will progress laterally and on the change of tide may return again. Again, those which are more shore-ward will have a similar zig-zag movement but forward in the direction of the waves and at the same time the periodic zig-zag of the tidal stream with the result that the path becomes a curved zig-zag towards the shore, with a bias in the direction of the littoral drift.

With an increase of wave height the resultant motion will be accelerated until those particles moving shore-wards find themselves in a veritable upheaval of strong waters in the plunge line and they are catapulted high and dry to a beach crest.

Now if this is at all a fair outline of the mechanism of the littoral drift then it is obvious that the supplies to the beaches are fundamentally fortuitious. They will vary, even over the same contours of the sea-bed, with the height and direction of the waves and the strength of the tidal ebb and flow and, in shallow water, upon the direction and strength of the wind. There may also be another factor, perhaps temporary or changeable, and that is the sizes, shapes, nature and presence of off-shore banks of material, which seem to have the quality of attracting, under or on water, of any loose material in the vicinity similar to the composition of the mass.

The sweep of IJme Bay from Budleigh Salterton to Chesil Bank, passing through Sidmouth, Beer, Seaton and Bridport, is 40 miles. To the west of Budleigh Salterton the beaches are sand, but to the east 
with the exception of small sheltered embayments, there is shingle. Budleigh Salterton is well supplied but from there towards Chesil it thins out into ribbons nestling again the cliffs and in places such as Seaton forming steep beaches above low water; then again along the cliffs it thins out to Bridport, where the beaches although well groyned have fluctuating supplies. From then on to the Chesil Bank the supplies must be considerable. It is also well to note that to the east for 3 miles beyond the tip of The Bill there is a large submerged shingle bank the Shambles, which also appears to be a permanency. Perhaps this latter takes the overflow from Chesil Bank. It seems apparent that the only solution to this mystery lies under water.

\section{TELEVISION.}

With the highly developed new television and echo sounding apparatus in the last decade it has been possible to examine the seabed in great detail and accuracy. For example comparatively recently some further confirmation of this was provided in the search, by salvage vessels carrying television apparatus and echo sounders, for the lost submarine "Affray" somewhere in the English Channel. To test the reliability of the camera and method a diver was sent down in 20 fathoms of water. The picture on the screen showed the diver on a sea-bed of shingle and coarse sand. It was estimated that the shingle sizes varied from half inoh pebbles to 3 inch shingle. The diver was then directed to take representative samples which he did whilst still observed on the screen. Later examination of the material confirmed the accuracy of the screen reading.

Another oceanographical detail of importance resulted from this memorable search. The echo sounder had revealed a steep ledge on the sea bottom and the possibility was that the lost vessel might be lying on the talus and thus be blended with the bottom topography. The whole area was therefore closely surveyed by the echo sounder which showed that the formation was a large almost semi circular sand bank lying on the bed in 280 feet of water. The bank crown was 60 feet high above the bed and was about 1500 feet diameter: the shape being very similar to an orange slice. The top surface was ripple marked. It may be remarked that $\mathrm{Dr}$. Van Veen has already called attention to the several series and wide distribution of similar banks along the coast of the Low Countries.

\section{NOURISHMENT OF BEACHES.}

Regarding beach mechanism from the plunge line to the shore we will assume that the principle of beach formation by waves as outlined by Bagnold is established and accepted. His laboratory experiments were concerned with wave crests parallel to the beach contours. There were no lateral forces and no tidal range. This lack however does not affect his main conclusions; they can be 
readily observed in nature, though of course modified. He showed that the step on a shingle beach at the plunge line lay between the lower beach shelf and the upper beach to the crest. He also showed the manner of breakdown of a beach when the crest at a wall, or nonporous backing, is submerged, and also the breakdown when the upper beach lies on an impervious layer. He stressed the importance of the porosity of the beach, and even suggested an open screen of closely spaced bars parallel to and in front of the sea wall as a preventive.

From this it will be appreciated that thinly covered and slightly nourished beaches of shingle lying over a stratum of low porosity, like Selsey Bill, are particularly vulnerable to bad weather at all stages of the tide; and any drastic interference with the beach, such as trench digging, pile driving and even holiday crowds, can only weaken its resistance. A false sense of security is engendered frequently where heaps of recently cast-up shingle lie landwards of the crest, such as the construction of the life boat house on the above-mentioned beach in 1918. I have even seen at Deal brick built buildings erected on shingle within a few feet of the crest. I have also seen them swept away by the sea.

I hold strongly to the belief that thinly nourished beaches which historically have seldom been otherwise are best defended by rearguard action, in other words, with longitudinal walls, or dykes, designed to match in with the natural profile of the beach; the toe being protected by sheet piling. In the construction no excavation of the original beach should be allowed, it would be preferable to leave the piling projecting above the beach and form the toe slope with quarry boulders to the talus necessary and half grout them with bitumeno

The beaches which are too highly nourished are mostly those to the weather side of large man-made constructions, either with that purpose in view, like the Twiss groyne at Hythe, or to prevent the material travelling forward in the natural way as at Shoreham harbour. At Durban and Salina Cruz the expensive solution was to pump the material under the harbour channel to the further shore. There must be some other more natural solution for in Nature it happens underwater. At Herme Bay the beach east of the pier is almost devoid of shingle whilst to the west of the pier it is very highly nourished. This ill-favoured beach is provided with groynes at $80-100$ feet spacing for about $\frac{3}{4}$ mile run. The same feature occurs in the West bay at Sidmouth where only stray shingle hugs the foot of the cliff's. At Weymouth the town beach is sand for 2000 feet and then merges into shingle.

This English coast is one of the most heavily groyned and walled shore lines in Europe and yet the problems besetting them do not lessen as the expense increases. Enormous quantities of material pass along the littoral and much is collected on the beaches and then 
suddenly it is washed away. Sometimes it is washed back again and sometimes not. The severe fluctuations have compelled the construction of strong longitudinal defences which for the greater part are self stable. Hazarding the implication of heresy, I sometimes wonder if all the groynes were demolished and the beaches left free, would the accumulation of shingle become better distributed, or would matters become worse. In the latter case where would the material go ?

CONITNENTAL COAST.

On the delightful beach at Ie Touquet I have seen and measured at low water springs the forward travel of one of the small inshore migratory banks. Le Touquet is devoid of defences with the exception of woven fences on the hinder beach to trap the wind blown sand, an exceedingly wise precaution. Proceeding northwards the sand beaches thin out about the rock ledges and cliffs of Pas de Calais but from Dunkirk to Le Zoute they become well nourished, although latterly not so well as 30 years ago. Holland, the country most deserving of the blessings of Nature, despite the presence of enormous travelling banks of sand out at sea is deprived of a sufficiency, maybe by reason of the several rivers' sstuaries from Le Zoute to the Hook of Holland. Further north sand again appears in quantity at Horns Reef, Denmark, and continues to the Skaw, where large deposits spread out over the entrance to the Baltic.

In Denmark, Holland and Belgium the common principle of coast defence comprises large stone groynes and substantial longitudinal dykes, or barriers. Denmark with small tidal range constructs massive concrete block and stone groynes to 4 feet above water level, (for constructional and maintenance convenience), and carries them landwards through the first line of sand barriers over the space separating that from the second line of barriers in which the end is rooted. Thus to some extent they form bulktueads, like the transversal walls at Arros and des Huttes, to limit breaches to compartments. Some success has been registered but not entire satisfaction. The function of these groynes was designed to be that of sand traps of the littoral drift.

In Holland the groynes are equally massive but the crowns slope almost parallel with the beach profile and are extended to below low water. The tidal range varies from about 7 feet in the north to 10 feet in the South. The sea extremities are pancaked out like an inverted scallop shell and the land ends are strongly rooted in the well-known Dutch type dykes, with paved stone facings and fascine reinforcement. The considerable tidal currents and the poor nourishment have led the Dutch engineers to the conclusion that the better plan to suit their conditions is to build substantial groynes to deflect the tidal stream from the shore, and this they do.

In Belgium the outstanding feature of defence was the maintenance of the beaches which in the past have been well nourished. The groynes 
were constructed to a form pleasing to the eye and of a streamine section to prevent turbulence about them。 The sea extremities were pancaked like the Dutch type. The se groynes have a long life and only in exceptional circumstances has it been necessary to carry out expensive repairs. They are rooted, usually in the tourist centres, in sturdy sloping walls of stone or brick facings and sand filled, with timber sheeting in the beach at the toe. At Ostende where the beaches have within recent years suffered depletion there is a wide apron in front of the toe, which I have noted has latterly been again widened. Noting that porosity is the all important factor: of beach building I am left to wonder why this was done. I know of several cases where this has had bad effects. There is also another point of importancer I have seen clouds of wind-blown sand swept off the Belgian beaches depriving them of the supplies so badly needed.

The systems adopted at Arros and des Huttes in France have much to be said in their favour. It is a compromise between north Furopean and Mediterranean practice of dependence on longitudinal walls irrespective of the aid of beaches. The method of construction of this new wall appears expensive and one questions whether the Italian method of boulder construction with bitumen grouting and spaced gaps had been considered. A coursed frontal wall on a sand beach submerged by the tide is prone to foundation erosion in gales at some height of water. I recall seeing at St. Malo, alongside the Sillon, during a storm, the beach cleft like a valley about a palisade groyne of natural tree trunks, by the turbulence of the clapotis about them. The sand was thrown up to the flanks in considerable heaps.

I make the submission that research work would be more valuable to practising engineers if it were more concerned with Nature in the raw, and with the aid of modern instruments to trace the sea-bed action under water. When all is said and done reduced model expericments are usually confined to ad hoc experiments and I contend that it is more preferable to know than to assume.

\section{REFERENCES.}

Bagnold, R.A. Beach Formation by Waves. Journal Inst. Civil Ingineers, Iondon, November 1940 .

Cornaglia, Paolo, Delle Spiagge. Atti della R. Accademia dei Iincei. Roma 1888. Della energia del flutto di fondo in mare. Giornale del Genio Civile. 1890.

D'Arrigo, Agatino. Leonardo da Vinci e il regime della spiaggia di Cesenatico. Roma. 1940. Ricerche sulle caratteristiche del Moto Ondoso nel Mediterraneo e sulla theoria del Cornaglia. Roma. 1937. 
de Rouvilie, A. Renseignement et reflexions sur les ouvrages de defense des côtes.. Annoles des Ponts et Chaussees No. 5. 1950. Paris.

Duvivier, J. The Problem of Coast Erosion. Journal Inst. Civil Engineers. London, 1947.

Lau wers, J. Ies marées des ports d'Ostende, de Zeebrugge et de Nieuport.

Minikin, $R_{0} R_{0}$ Coast Erosion and Protection, Chapman and Hall. London. 1952.

Per Bruun. The Danish West Coast. The Dock and Harbour Authority. No. 359. Vol. XXXI. 1950.

Stephenson, A.G. Shoreham Harbour. The Dock and Harbour Authority. No. 342. Vol. XXIX. 1949.

Van Veen, J. Fnglish and Dutch Methods of Shore Protection. The Dock and Harbour Authority. No. 379. Vol. XXXIII. 1952. Research of Tidal Rivers in the Netherlands. The Dock and Harbour Authority, November and December 1946.

\section{RESUL1B}

\section{PRIMCIPES FONDAMENTAUX DE L'EROSION DES COTES}

\section{R. R. Minikin}

Cette communication se rapporte aux pxinolpes fondamentaux de l'érosion dos côtes et de leur protection : le sujet est abordé sous l'anglo de l'art de l'Ingénieur. Ce mémoire est le résultat des études et des réfloxions de l'auteur suggérées par des observations personnelles sur des portions étendues des côtes européennes. Il est plus intéressé dans les observations visuelles sur Nature que par les théories. ou les tentatives de généralisation ot, pour illustrer son argumentation, il donne de brèves descriptions de plusieurs plages importantes du littoral ouropéen. Celles. oi sont considérées comme offrant des aspects particuliers ou prédominants dos phénomènes côtiers, qui permettraient de découvrir los secrets oachés dont l'existence a été soupçonnéo depuis longtemps par les ingénieurs et les chercheurs.

La thèse est que les problèmes encore non résolus sont beaucoup plus propres à tre démêlés sur des plages naturelles qui ont des tenđances prédominantes plus stables que dans un laboratoire.

Il en est ajnsi spécialement de nos jours, depuis que le développement moderne de la télévision sous-marine et des appareils de sondage par écho autorisent un examen serré et précis du fond de la mer. 
Plusieurs pays ont abordé de manières divorses le problème de la défense des côtes; cela tient à ce que les opinions concernant le ohoix du phénomène - ou du groupe de phénomènes prépondérants - varient beaucoup. I'auteur suggèro qu'il y a uno érosion favorablo aussi bien qu'uno nuisible ot que lo temps et I'argont dépensés on travaux pour diminuer la première peuvent en conséquonce accrostre la soconde. Ceci, oertes, s'applique soulement aux pays favorisés par des falaises rocheuses, tandis que, sur les côtes des pays surbaissés, qui sont protégées prinoipalement par des constructions artificielles, toute érosion est nuisible.

Référenco est faite au fond d'information maritime recuellil et publié par les Instituts Océanographiques existants, ot particulierement par lo plus ancion de ceux-ci, celui de Naplos. Sous de rapport on de rappello que le grand léonard de Vincl s'ocoupait des problèmes do l'érosion des cótes à Cejenatico dans l'Adriatique et au Havro. Son esprit tonace ot analytiquo a noté plisiours des faits fondamentaux du oomportemont de la mor vis-à-vis dos rivagcs avancés ot sos solutions conotituent peut-êtro los basos de la pratique Méditorranéenno d'aujourd'hui. Le conoopt do la "ligno neutro" est da à un autre attontif ingéniour italion, Paolo Carnaglia (1890).

L'espoir de résultats immédiatoment favorables ne doit pas être conservé ; les plagos los plus durablos croissent graduellement, celies qui se forment on une marée ou deux sont davantage propres à disparaitre beauooup plus rapidement sur un changement des conditions météorologiques.

Ia suggestion est faite que les travaux de défense doivent avoir pour but de créer des tendances favorables dans la tenue de la plage, plutôt que de façonner des barrières ou des brise-lames.

En résumé, l'auteur suggère que le concept du transport solide du littoral réclame une compréhonsion plus profonde, que ce n'est pas oimplement le transfert on masse de parcelles de matériaux insolubles le long du littoral par une mer bénéfique; le cuncept en cause comprend plus que oela. I'acoent ost mis sur lo fait qu'avec les nouveaux appareils de télévision sous-maxine, etc..., les Unités de la Varine Nationale affectées aux recherchos on mer devraiont assumer la tâohe d'explorer le fond de la mer en bordure du littoral.

La plus grande pertio dos mesures de protection se présente sous la forme d'un systèmo do musoirs implantés dans los bords de la mer ou de digues, dans le but de capter los matériaux de transport solide du littoral, de manière à formor des plages de proteotion; toutefois, d'autres systèmes similaires ont été conçus pour déflecter le courant de marée loin de la ligne côtière. Ces solutions divergentes peuvent-elles être conciliées?

L'auteur estime que les systèmes basés sur les modèles belges ou italiens d'il y a 30 ans offrent les solutions les plus propres à une défense durable, mais qu'ils doivent tre gradués par uno oonnalssance serrée des conditions de site du littoral et par un sens personnel de la mer. 